Prosiding Seminar Nasional Pendidik dan Pengembang Pendidikan Indonesia dengan Tema "Peningkatan Profesionalisme Pendidik di era Revolusi Industri 4.0”. Pendopo Gubernur NTB 27 Oktober 2018. ISSN 2598-1978

\title{
INTERNALISASI NILAI KARAKTER DALAM PEMBELAJARAN SAINS BERBASIS MODEL PEMBELAJARAN KARAKTER ESD UNTUK MEMPERSIAPKAN GENERASI EMAS 2045
}

\author{
Amran Amran', Magfirah Perkasa ${ }^{2}$, Muhammad Satriawan ${ }^{3}$ dan Ismail Jasin ${ }^{1}$ \\ ${ }^{1}$ Pendidikan Biologi STKIP Bima \\ ${ }^{2}$ Pendidikan Kimia STKIP Bima \\ ${ }^{3}$ Pendidikan Fisika STKIP Bima \\ e-mail: $\underline{\text { ran_bima@yahoo.com }}$
}

\begin{abstract}
Abstrak: Indonesia pada tahun 2045 akan merayakan 100 tahun kemerdekaan sehingga momentum ini akan menjadi tolak ukur ketercapaian dan keberhasilan pembangunan Indonesia dalam berbagai bidang, salah satunya bidang pendidikan dan pemberdayaan SDM. Bonus demografi dimana usia produktif masyarakat Indonesia yang paling besar akan menjadi bahan baku utama yang harus diberdayakan dengan baik. Pendidikan sebagai salah satu pilar pembangunan SDM perlu melakukan inovasi agar bonus demografi ini dapat diarahkan ke arah yang positif dan dapat mewujudkan cita-cita Indonesia untuk membentuk generasi 2045. Penelitian ini bertujuan untuk meningkatkan sikap siswa dan menyisipkan nilai karakter dalam pembelajaran sains berbasis model pembelajaran karakter ESD untuk mempersiapkan generasi emas Indonesia 2045. Nilai karakter yang diukur yaitu karakter abad 21 yang meliputi: kritis, kreatif, kerjasama dan kemampuan komunikasi. Penelitian ini merupakan desk study dengan desain penelitian tindakan kelas dengan satu siklus. Instrumen pengumpulan data meliputi lembar penilaian diri dan lembar observasi. Hasil penelitian menunjukkan bahwa terdapat peningkatan sikap dan karakter siswa dalam pembelajaran menggunakan model pembelajaran karakter ESD.
\end{abstract}

\section{Kata Kunci: Karakter, Model Pembelajaran Karakter ESD, Generasi Emas 2045, Pembelajaran Sains}

\section{PENDAHULUAN}

Indonesia akan merayakan 100 tahun kemerdekaan pada tahun 2045. Momentum ini akan menjadi tolak ukur ketercapaian dan keberhasilan pembangunan Indonesia dalam berbagai bidang, salah satunya bidang pendidikan dan pemberdayaan SDM. Salah satu bonus yang akan diperoleh Indonesia pada momentum tersebut yaitu bonus demografi dimana jumlah usia produktif Indonesia pada kurun waktu 2010-2045 diprediksi sebagai jumlah paling besar sepanjang sejarah. Jumlah usia produktif ini harus diberdayakan dengan baik sehingga dapat memberikan keuntungan (demographic benefit) dan dapat menjadi sumber daya manusia (SDM) yang menjadi ujung tombak pembangunan Indonesia untuk lebih maju. Jika kesempatan ini dapat dikelola dan diberdayakan dengan baik, maka jumlah usia produktif Indonesia ini akan menjadi bonus demografi yang sangat berharga. Sebaliknya, jika tidak dikelola dengan baik, maka jumlah usia produktif yang dimiliki oleh Indonesia justru akan menjadi bencana demografi (demographic disaster) yang berdampak pada stabilitas negara (Dongoran, 2014).

Pendidikan merupakan sebuah pilar yang memiliki peranan stategis dalam mengembangkan sumber daya manusia yang berkualitas. Oleh karena itu, sangat penting untuk merokunstruksi dan mereformulasi desain pendidikan yang dapat mendukung terciptanya generasi emas bangsa Indonesia. Generasi yang berkarakter generasi emas harus memiliki kompetensi, karakter, nilai religius, sikap, pola pikir, konsep, dan berperadaban unggul dengan wawasan yang cerdas serta berpikiran berkelanjutan sehingga menumbuhkan tanggung jawab dan kontribusi nyata dalam mewujudkan lingkungan dan kehidupan yang sehat, damai, bermartabat, dan berkelanjutan seutuhnya. Kemendikbud menguraikan karakter generasi emas sesuai dengan nilai pendidikan karakter memuat nilai sikap religius, jujur, toleransi terhadap keberagaman, disiplin, kerja keras, kreatif, mandiri, demokratis, rasa ingin tahu, semangat nasionalisme, cinta tanah air, berprestasi, 
komunikatif, cinta damai, gemar membaca, peduli lingkungan, peduli sosial dan bertanggung jawab (Agus, 2016; Fahmy, et al., 2015; Manullang, 2013).

Permalasahan tentang bergesernya nilai-nilai karakter generasi muda semakin marak akhirakhir ini. Beberapa kasus tentang kurangnya kepedulian sosial dan profesionalisme muncul karena dangkalnya penanaman karakter serta tidak tersisipnya nilai-nilai karakter mulia dalam proses pembelajaran sejak dini. Media massa saat ini dihiasi oleh pemberitaan tentang karakter dan sikap generasi muda yang mengarah pada hal-hal negatif. Jika dibiarkan tanpa pengendalian, penanaman, pengembangan dan penguatan karakter sejak dini, maka permasalahan seperti ini akan menjadi ciri khas negatif dari generasi yang akan datang.

Hal ini terjadi salah satunya karena tidak tersisipnya nilai-nilai karakter dalam proses pembelajaran. Berdasarkan hasil wawancara singkat dengan perwakilan guru dan akademisi LPTK di beberapa kabupaten di Provinsi Nusa Tenggara Barat, pembelajaran berbasis penguatan pendidikan karakter serta pendidikan untuk pengembangan berkelanjutan yang memuat nilai-nilai dan wawasan berkelanjutan juga belum diimplementasikan secara luas dalam pendidikan. Kompetensi tersebut masih dianggap asing dan hampir tidak pernah dinilai dengan baik serta minim disisipkan dalam proses pembelajaran oleh guru maupun dosen sehingga masih banyak generasi muda yang belum memiliki kesadaran beretika dan penguasaan emosi, menguasai literasi digital dan informasi serta keterampilan berkomunikasi dan berkolaborasi dalam proses pembelajaran maupun kesehariannya. Permasalahan lain yang juga dihadapi oleh pendidik pada masa sekarang adalah tidak tersedianya inovasi pembelajaran berupa model pembelajaran berkarakter yang dapat dijadikan landasan penerapan dalam proses pembelajaran untuk menumbuhkembangkan sikap dan karakter mulia, bahkan di pendidikan dasar.

Pada pembelajaran sains terdapat dimensi yang berkaitan dengan sikap ilmiah. Sikap ilmiah juga memuat nilai sikap yang selaras dengan nilai pendidikan karakter. Konsep education for sustainable development juga memuat nilai sikap yang berkaitan dengan pendidikan karakter. HEPS (2004; 9) menguraikan bahwa seseorang yang memiliki literasi dan wawasan berkelanjutan diharapkan untuk:

1. Memahami kebutuhan untuk perubahan kehidupan berbasis pembangunan berkelanjutan dalam setiap hal, baik secara individu maupun bersama. Indikator ini berkaitan dengan nilai sikap jujur, komunikatif, peduli sosial dan bertanggung jawab.

2. Memiliki pengetahuan dan keterampilan yang cukup untuk memutuskan dan melakukan perubahan untuk pengembangan berkelanjutan. Pada kompetensi ini, nilai pendidikan karakter yang dapat terintegrasi yaitu rasa ingin tahu, gemar membaca, kreatif, kritis, komunikasi, berprestasi, peduli sosial dan peduli lingkungan.

3. Mampu mengenali dan memberi apresiasi pada keputusan dan tindakan orang lain dalam melakukan perubahan untuk pengembangan berkelanjutan yang bijak dan tepat. Nilai sikap yang dapat ditumbuhkembangkan pada kompetensi ini yaitu toleransi terhadap keberagaman, disiplin, kerja keras, kreatif, mandiri, demokratis, rasa ingin tahu, semangat nasionalisme, cinta tanah air, berprestasi, komunikatif, cinta damai, gemar membaca, peduli lingkungan, peduli sosial dan bertanggung jawab.

Strategi dan model pembelajaran untuk mengintegrasikan nilai pendidikan karakter dan nilai konsep sustainable development masih terbatas (Perkasa, 2017; Perkasa, 2015; UNESCO, 2002: 5).

Nilai ini dapat disisipkan dalam pembelajaran sains melalui internalisasi nilai pendidikan karakter melalui strategi dan model pembelajaran yang tepat. Salah satu model pembelajaran yang direkomendasikan untuk dapat mengitegrasikan nilai pendidikan karakter yaitu model pembelajaran karakter ESD. Oleh karena itu, studi ini mengkaji tentang internalisasi nilai pendidikan karakter dalam pembelajaran sains melalui model pembelajaran karakter ESD untuk mempersiapkan generasi emas 2045.

\section{METODE PENELITIAN}

Jenis penelitian ini merupakan penelitian deskriptif (desk study) dengan perspektif tindakan kelas dengan satu siklus yang bertujuan untuk mengkaji internalisasi nilai pendidikan karakter 
dalam pembelajaran sains melalui model pembelajaran karakter ESD untuk mempersiapkan generasi emas 2045. Hasil kajian ini berdasarkan hasil need assesment yang telah dilakukan dalam mengembangkan model pembelajaran karakter ESD. Subjek need assessment yaitu enam SMA yang berada di wilayah Provinsi Nusa Tenggara Barat. Nilai karakter yang diukur yaitu karakter abad 21 yang meliputi: kritis, kreatif, kerjasama dan kemampuan komunikasi. Instrumen pengumpulan data meliputi lembar penilaian diri dan lembar observasi.

\section{HASIL DAN PEMBAHASAN}

\section{Need Assesment}

Need assesment dilakukan untuk memperoleh data awal sehingga dapat menjadi landasan kajian studi ini. Need assesment juga dapat memberikan gambaran data yang nyata dalam pengkajian studi ini. Beberapa sekolah dijadikan lokasi studi pendahuluan dengan melakukan wawancara singkat dengan guru mata pelajaran kimia, biologi dan fisika yaitu: SMAN 2 Kota Bima, SMAN 1 Bolo (Kab.Bima), SMAN 1 Dompu (Kab. Dompu), SMAN 2 Dompu (Kab. Dompu), SMAN 1 Kota Mataram, SMAN 3 Kota Mataram, SMAN 1 Gunungsari (Kab. Lombok Barat), dan SMAN 1 Narmada (Kab. Lombok Barat). Namun, need assesment hanya dilakukan pada enam sekolah diantara delapan sekolah tersebut, yaitu SMAN 2 Kota Bima, SMAN 1 Bolo (Kab.Bima), SMAN 1 Dompu (Kab. Dompu), SMAN 2 Dompu (Kab. Dompu), SMAN 3 Kota Mataram dan SMAN 1 Narmada (Kab. Lombok Barat). Need assesment juga sebatas sikap yang dituntut pada kehidupan abad 21 yang berkaitan dengan 4Cs (communication, critical thinking, collaboration \& creativity).

Berdasarkan hasil wawancara, observasi dan need assesment yang dilakukan pada enam sekolah tersebut, diperoleh informasi bahwa:

1. Model pembelajaran untuk mengimplementasikan konsep pendidikan karakter belum ada dan belum diajarkan oleh para guru;

2. Sebagian guru belum mengetahui tentang konsep pendidikan berbasis lingkungan, education for sustainable development dalam implementasi pembelajaran sains;

3. Sebagian para guru masih menitikberatkan evaluasi pembelajaran sains pada penilaian aspek pengetahuan;

4. Penilaian aspek sikap dan keterampilan khususnya yang berkaitan dengan nilai karakter bangsa dan pendidikan karakter masih minim dilakukan dalam proses pembelajaran.

\section{Analisis}

Analisis siswa dilakukan dengan menganalisis hasil need assesment siswa yang berkaitan dengan sikap yang dituntut pada kehidupan abad 21 yang berkaitan dengan 4Cs (communication, critical thinking, collaboration \& creativity). Indikator 4Cs diadaptasi dari Partnership for 21st Century (P21) (Griffin, et al., 2012; P21, 2011). Berdasarkan hasil angket siswa tentang kebiasaan sehari-hari mereka yang berhubungan dengan karakter dan nilai pendidikan karakter menggambarkan bahwa siswa memiliki pengetahuan yang cukup baik tentang perilaku sesuai nilainilai pendidikan karakter namun belum terlihat dalam keseharian siswa. Hasil need assesment siswa ditunjukkan pada Tabel 1.

Tabel 1. Hasil Need Assesment Sikap Abad 21

\section{Sikap Abad 21}

\begin{tabular}{|c|c|c|c|c|c|c|c|c|c|c|c|c|}
\hline \multirow{4}{*}{$\begin{array}{c}\text { Jumlah } \\
\text { Sampel Tiap } \\
\text { Sekolah }\left(\sum\right)\end{array}$} & \multirow{2}{*}{\multicolumn{3}{|c|}{ Critical Thinking }} & \multicolumn{6}{|c|}{ Sikap Abad 21} & \\
\hline & & & & Coll & llaborat & tion & Com & munic & cation & & Creativ & \\
\hline & Ting & Culvun & Rend & Tingg & Cuku & Rend & Tingg & Cuk & Rend & Ting & Cuku & Renda \\
\hline & gi & & ah & $\mathbf{i}$ & $\mathbf{p}$ & $\mathbf{a h}$ & $\mathbf{i}$ & up & ah & gi & $\mathbf{p}$ & h \\
\hline $\begin{array}{c}\text { A } \\
(35 \text { siswa })\end{array}$ & - & 8 & 27 & - & 11 & 24 & 1 & 13 & 21 & - & 8 & 27 \\
\hline $\begin{array}{c}\mathrm{B} \\
(27 \text { siswa) }\end{array}$ & - & 6 & 21 & - & 2 & 25 & - & 17 & 10 & - & 11 & 16 \\
\hline $\begin{array}{c}\mathrm{C} \\
(32 \text { siswa) }\end{array}$ & - & 4 & 28 & 2 & 7 & 26 & 1 & 11 & 23 & - & 3 & 29 \\
\hline D & - & 7 & 23 & - & 14 & 16 & - & 15 & 15 & - & 5 & 25 \\
\hline
\end{tabular}


Prosiding Seminar Nasional Pendidik dan Pengembang Pendidikan Indonesia dengan Tema "Peningkatan Profesionalisme Pendidik di era Revolusi Industri 4.0”. Pendopo Gubernur NTB 27 Oktober 2018. ISSN 2598-1978

$\begin{array}{lcccccccccccc}(30 \text { siswa) } & & & & & & & & & \\ \text { E } & - & 8 & 24 & 5 & 15 & 12 & 2 & 13 & 17 & - & 5 & 27 \\ (32 \text { siswa) } & & & & & & & & & & & & \\ \text { F } & - & 6 & 22 & - & 10 & 18 & 1 & 7 & 20 & - & 4 & 24 \\ (28 \text { siswa) } & & 39 & 145 & 7 & 59 & 121 & 5 & 76 & 106 & 0 & 36 & 148 \\ \text { Total } & 0 & 39 & \end{array}$

Berdasarkan Tabel 1 diperoleh informasi bahwa sebagian besar siswa pada semua sikap abad 21 belum mampu mencapai kategori tinggi. Sebaran data siswa masih terbilang banyak pada kategori rendah. Hal ini menunjukkan bahwa sikap pembelajaran abad 21 dan nilai karakter memang penting dan urgen untuk disisipkan dalam pembelajaran. Internalisasi nilai pendidikan karakter melalui pembelajaran ini dapat dilaksanakan dengan menerapkan model pembelajaran karakter ESD.

\section{Model Pembelajaran Karakter ESD}

Model Pembelajaran Karakter ESD memiliki tujuan untuk membentuk karakter siswa sesuai nilai dalam pendidikan karakter dan tuntutan abad 21. Karakter yang diharapkan dapat disisipkan melalui model pembelajaran karakter ESD yaitu: religius, jujur, toleransi terhadap keberagaman, disiplin, kerja keras, kreatif, mandiri, demokratis, rasa ingin tahu, semangat nasionalisme, cinta tanah air, berprestasi, komunikatif, cinta damai, gemar membaca, peduli lingkungan, peduli sosial dan bertanggung jawab.

1. Kumpulkan

Berikut diuraikan sintaks model pembelajaran karakter ESD:

Pada tahap ini, informasi tentang materi pembelajaran dan aplikasinya dalam kehidupan sehari-hari dibelajarkan melalui metode studi kasus dan brainstorming. Siswa diarahkan untuk mengumpulkan informasi yang berkaitan dengan materi pembelajaran dari lingkungan sekitar sekolah maupun tempat tinggal siswa. Informasi tersebut dapat berupa masalah yang sedang dihadapi masyarakat sekitar maupun yang menjadi gejala masalah yang belum meresahkan masyarakat. Masalah juga dapat dikumpulkan di lingkungan sekolah. Pada tahap ini, diharapkan sikap yang muncul yaitu toleransi, kreatif, rasa ingin tahu, komunikatif, peduli sosial, peduli lingkungan dan tanggung jawab.

2. Rembukkan

Informasi tentang materi pembelajaran dalam bentuk masalah yang telah dikumpulkan selanjutnya dirembukkan bersama rekan sekelompok. Pada tahap ini juga siswa dapat merembukkan bersama rekan sekelompok tentang kemungkinan alternatif solusi terhadap isu permasalahan yang telah dikumpulkan. Sikap yang diharapkan muncul pada tahap ini yaitu: toleransi, disiplin, kerja keras, kreatif, mandiri, demokratis, rasa ingin tahu cinta damai.

3. Analisis

Tahap analisis merupakan tahap untuk menganalisis lebih lanjut dan lebih rasional serta mengolah informasi tentang kemungkinan alternatif solusi. Pada tahap ini, alternatif solusi yang disediakan dianalisis lebih lanjut hingga siswa dapat memilih solusi yang paling sesuai untuk dapat diterapkan sebagai penyelesaian masalah. Sikap yang diharapkan dapat disisipkan melalui tahapan ini yaitu: jujur, toleransi terhadap keberagaman, disiplin, kerja keras, kreatif, mandiri, rasa ingin tahu, semangat nasionalisme, cinta tanah air, berprestasi, cinta damai, peduli lingkungan, peduli sosial dan bertanggung jawab.

4. Komunikasikan

Solusi yang paling sesuai dengan kondisi atau isu permasalahan selanjutnya dikomunikasikan kepada guru maupun perwakilan masyarakat.yang menjadi target masalah. Komunikasi yang baik antara guru, rekan sekelompok maupun masyarakat target masalah dapat merangsang siswa untuk dapat mengembangkan dan menumbuhkan sikap religius, hormat pada yang lebih tua, jujur, toleransi terhadap keberagaman, disiplin, kerja keras, kreatif, mandiri, demokratissemangat nasionalisme, cinta tanah air, berprestasi, komunikatif, cinta damai, peduli lingkungan, peduli sosial dan bertanggung jawab 
5. Terapkan

Tahapan terakhir dari sintaks model pembelajaran karakter ESD yaitu "terapkan". Pada tahapan ini, alternatif solusi yang telah dipilih tidak hanya dikomunikasikan kepada guru maupun perwakilan masyarakat target, tetapi juga langsung diterapkan agar keberfungsian alternatif solusi tersebut dapat dioptimalkan hasilnya. Sikap yang diharapkan muncul yaitu: religius, jujur, toleransi terhadap keberagaman, disiplin, kerja keras, kreatif, mandiri, demokratis, rasa ingin tahu, semangat nasionalisme, cinta tanah air, berprestasi, komunikatif, cinta damai, gemar membaca, peduli lingkungan, peduli sosial dan bertanggung jawab.

Gambaran sintaks model pembelaajran karakter ESD ditunjukkan pada Gambar 1.

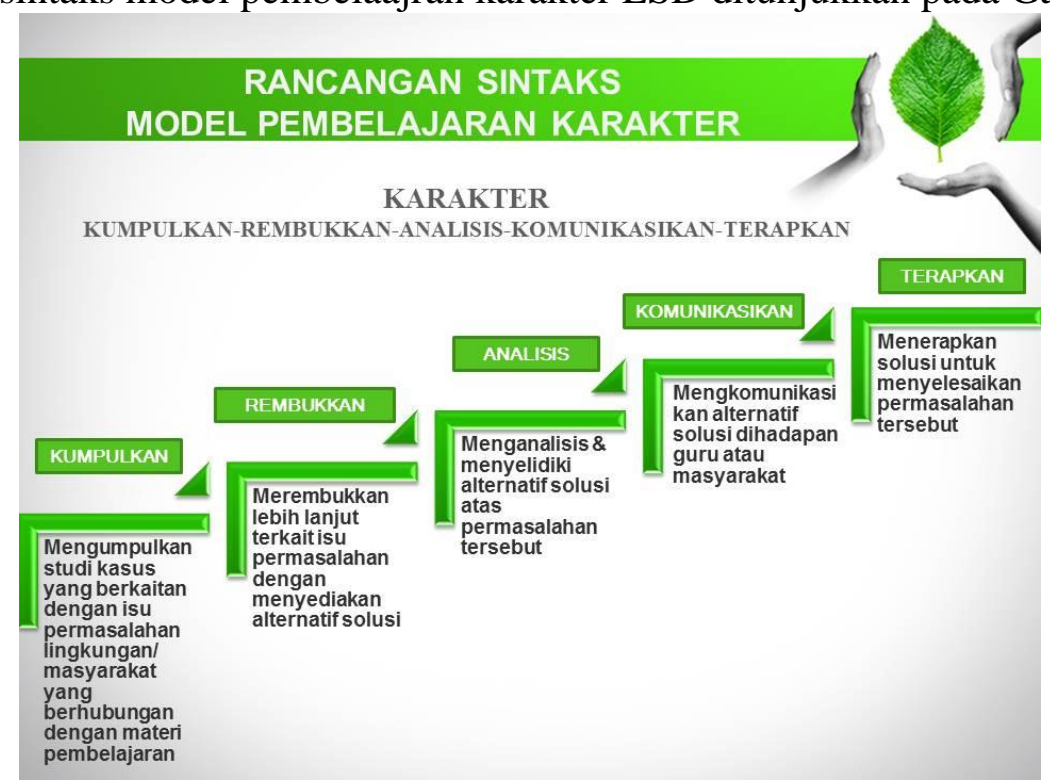

Gambar 1. Sintaks Model Pembelajaran Karakter ESD

Model pembelajaran karakter ESD memiliki karakteristik dan batasan, yang diuraikan berikut:

1. Model pembelajaran karakter ESD hanya dapat diterapkan pada materi yang memiliki karakteristik dapat dikaitkan dengan kehidupan sehari-hari (kontekstual) dan sesuai dengan topik dalam konsep pengembangan berkelanjutan yaitu masyarakat, ekonomi dan lingkungan,

2. Bertujuan untuk pembentukan sikap dan karakter sehingga tidak bertujuan langsung untuk peningkatan aspek pengetahuan maupun keterampilan, walaupun dalam pelaksanaan dan penilaiannya tetap disisipkan aspek pengetahuan dan keterampilan,

3. Hanya dapat diterapkan untuk mata pelajaran yang eksak (ilmu pengetahuan alam dan bidangnya),

4. Dapat menjadi salah satu model pembelajaran untuk mengajarkan konsep pendidikan karakter dan konsep pendidikan untuk pengembangan berkelanjutan (education for sustainable development).

Kelebihan dan kekurangan dari model pembelajaran karakter ESD diuraikan:

1. Kelebihan

a. Dapat menjadi salah satu model pembelajaran untuk mengajarkan konsep pendidikan karakter dan konsep pendidikan untuk pengembangan berkelanjutan (education for sustainable development) yang masih belum tersedia model pembelajaran representatifnya selama ini,

b. Apabila diterapkan dengan baik serta dinilai dengan baik, diprediksi dapat menjadi langkah praktis untuk penguatan pendidikan karakter,

c. Melibatkan prinsip reaksi dari berbagai pihak, termasuk masyarakat sekitar sekolah dan orangtua untuk dapat berpartisipasi dalam pembelajaran sebagai kontrol dan mediator.

d. Dapat menjadi salah satu alternatif model pembelajaran untuk pembelajaran abad 21 . 


\section{Kekurangan}

a. Waktu pelaksanaan yang relatif membutuhkan waktu tidak singkat.

b. Kemungkinan terjadinya miskomunikasi antara pihak yang terlibat.

Model pembelajaran karakter ESD dapat diterapkan dalam pembelajaran dengan menggunakan RPP, LKS dan instrumen penilaian yang sesuai dan telah dianalisis terlebih dahulu (subject specific pedagogy). RPP merupakan seluruh rangkaian kegiatan pembelajaran untuk mencapai tujuan pembelajaran yang ditentukan tiap satu kali pertemuan atau lebih. RPP disusun berdasarkan Kurikulum 2013 yang disusun dengan model pembelajaran karakter yang disesuaikan dengan pendekatan saintifik. Mendikbud (2013: 6) menyatakan sistematika RPP yang disusun dengan kurikulum 2013 memiliki muatan yang dijabarkan sebagai berikut: identitas sekolah; identitas mata pelajaran; kelas/semester; materi pokok; alokasi waktu; tujuan pembelajaran yang dirumuskan berdasarkan KD; kompetensi dasar dan indikator pencapaian kompetensi; materi pembelajaran; metode pembelajaran; media pembelajaran; sumber belajar; langkah pembelajaran; dan penilaian hasil pembelajaran.

RPP memuat tiga kegiatan utama yang mencakup: pendahuluan, inti dan penutup. Kegiatan pendahuluan berisi hal-hal yang dilakukan untuk memusatkan perhatian siswa melalui apersepsi dan motivasi serta untuk menyampaikan tujuan yang ingin dicapai kepada siswa pada pertemuan tersebut. Kegiatan inti memuat pelaksanaan pembelajaran yang berorientasi pada pencapaian tujuan pembelajaran yang ditentukan. Kegiatan ini memuat beberapa langkah sesuai dengan sintaks model pembelajaran karakter ESD yaitu: kumpulkan, rembukkan, analisis, komunikasikan dan terapkan. Pada kegiatan inti, sintaks model pembelajaran karakter ESD disesuaikan dengan sintaks pendekatan saintifik yang telah ditetapkan yang disebut dengan 5M yaitu: mengamati, menanya, mengeksperimenkan atau mengeksplorasi, mengasosiasi dan mengkomunikasikan. Kegiatan penutup bertujuan untuk mengkonfirmasi pelaksanaan pembelajaran dan mengevaluasi ketercapaian tujuan pembelajaran pada pertemuan tersebut.

LKS disusun dengan menggunakan sintaks model pembelajaran karakter ESD yaitu kumpulkan, rembukkan, analisis, komunikasikan dan terapkan. Terdapat beberapa sikap (karakter) yang menjadi objek penilaian dalam penerapan model pembelajaran karakter ESD yaitu: jujur, toleransi terhadap keberagaman, disiplin, kerja keras, kreatif, mandiri, demokratis, rasa ingin tahu, semangat nasionalisme, cinta tanah air, berprestasi, komunikatif, cinta damai, gemar membaca, peduli lingkungan, peduli sosial dan bertanggung jawab.

Internalisasi nilai pendidikan karakter dalam pembelajaran sains dapat dioptimalkan dengan menerapkan model pembelajaran karakter ESD karena tujuan pengembangan model tersebut sudah berdasarkan analisis nilai pendidikan karakter, sehingga cita-cita bangsa Indonesia untuk mewujudkan generasi emas pada tahun 2045 dapat terwujudkan melalui kontribusi penerapan model pembelajaran karakter ESD.

\section{SIMPULAN \\ Simpulan}

Berdasarkan hasil need assesment, analisis dan pengkajian, dapat disimpulkan bahwa secara teori diasumsikan terdapat peningkatan sikap dan karakter siswa dalam pembelajaran sains menggunakan model pembelajaran karakter ESD. Hal ini menunjukkan bahwa internalisasi nilai pendidikan karakter dalam pembelajaran sains dapat dioptimalkan dengan menerapkan model pembelajaran karakter ESD untuk mempersiapkan generasi emas 2045.

\section{UCAPAN TERIMA KASIH}

Penulis mengucapkan terima kasih kepada Direktorat Riset dan Pengabdian Masyarakat, Kemenritekdikti yang telah membantu pendanaan penelitian ini melalui hibah penelitian strategis nasional (institusi).

\section{DAFTAR RUJUKAN}

Agus, C. (2016, Mei 10). Pendidikan untuk Generasi Emas. Harian Bernas, hal. 4. 
Dongoran, F. R. (2014, April). Paradigma Membangun Generasi Emas 2045 Dalam Perspektif Filsafat Pendidikan. Jurnal Tabularasa PPs UNIMED, 11(1), 61-76.

Fahmy, R., Bachtiar, N., Rahim, R., \& Malik, M. (2015). Measuring Student Perceptions to Personal Characters Building in education: An Indonesian Case in Implementing A New Curriculum in High School. Procedia - Social and Behavioral Sciences, 211, 851 - 858.

Griffin, P., McGaw, B., \& Care, E. (2012). Assessment and Teaching of 21st Century Skills. Dordrecht, NL: Springer.

HEPS. (2004). Learning and Skills for Sustainable Development: Developing a sustainability literate society. London: Severnprint.

Kemendikbud. (2013b). Peraturan Menteri Pendidikan dan Kebudayaan RI No. 65 Tahun 2013 tentang Standar Proses Pendidikan Dasar dan Menengah.

Manullang, B. (2013). Grand Desain Pendidikan Karakter Generasi Emas 2045. Jurnal Pendidikan Karakter, 3(1), 1-14.

P21. (2011). Framework for 21st Century Learning. Washington DC: Partnership for 21st Century.

Perkasa, M., \& Aznam, N. (2016). Pengembangan SSP Kimia Berbasis Pendidikan Berkelanjutan untuk Meningkatkan Literasi Kimia dan Kesadaran Terhadap Lingkungan. Jurnal Inovasi Pendidikan IPA, 2(1), 46-57.

Perkasa, M., \& Wiraningtyas , A. (2017). Pembelajaran Kimia Berorientasi Sustainable Development untuk Meningkatkan Kesadaran Siswa Terhadap Lingkungan. Jurnal Sainsmat, VI(2), 63-72.

UNESCO. (2002). Teaching and Learning for A Sustainable Future. Australia: Griffith University Publisher. 